\title{
Special issue: European Integration: Quo Vadis? Selected Papers from the 2013 Annual Meeting of the Austrian Economic Association
}

\author{
Michael Pfaffermayr $\cdot$ Johann Scharler
}

Published online: 9 April 2014

(C) Springer Science+Business Media New York 2014

In recent decades, European integration has made major steps forward. Yet, since the financial crises 2008/2009 severe disequilibria became manifest questioning the sustainability and the further development of European integration. Specifically, within the European Monetary Union these disequilibria are reflected in large trade deficits, capital outflows, fiscal deficits and the accumulation of large amounts of debt in some of its member states. The conference took a long-run view of the European integration process focusing on the economic mechanisms and policies required to promote sustainable growth and further integration in Europe.

The 2013 Annual Meeting of the Austrian Economic Association took place at the University of Innsbruck on 10-11 May 2013. Two papers taking up these issues from different perspectives contribute to the present special issue of Empirica.

The paper by Matthias Firgo and Peter Huber "Convergence as a heterogeneous process: what can be learnt about convergence in EMU from regional experiences" analyzes the anatomy of regional growth and convergence processes in Europe from 1991 to 2009 focusing on within-country, regional developments in the framework of currency unions. The findings suggest that the road to unconditional withincountry convergence is a discontinuous process and far from being granted. Furthermore, the econometric analysis identifies human capital and innovation as the main driving forces for unconditional long-run convergence.

Reinhard Neck and Dmitri Blueschke study a dynamic game between two countries in a monetary union in their paper "Haircuts" for the EMU Periphery: Virtue or Vice? In their simulations, they find that a haircut is disadvantageous for both countries of the monetary union, even when the countries are heterogeneous with respect to sovereign debt levels.

M. Pfaffermayr $(\bowtie) \cdot J$. Scharler

Innsbruck, Austria

e-mail: Michael.Pfaffermayr@uibk.ac.at 